\title{
Thermasporomyces composti gen. nov., sp. nov., a thermophilic actinomycete isolated from compost
}

Correspondence
Shuhei Yabe
kennan-6@kennan-e.co.jp

\author{
Shuhei Yabe, ${ }^{1}$ Yoshifumi Aiba, ${ }^{2,3}$ Yasuteru Sakai, ${ }^{1}$ Masaru Hazaka ${ }^{1}$ \\ and Akira Yokota ${ }^{2}$
${ }^{1}$ Hazaka Plant Research Center, Kennan Eisei Kogyo Co., Ltd, 44 Aza-Inariyama, Oaza-Ashitate, Murata-cho, Shibata-gun, Miyagi 989-1311, Japan
${ }^{2}$ Institute of Molecular and Cellular Biosciences, The University of Tokyo, 1-1-1 Yayoi Bunkyo-ku, Tokyo 113-0032, Japan
${ }^{3}$ F. T. Innovation, 6F Royal Ikebukuro Bldg., 39-9, Nishi-Ikebukuro 2-chome Toshima-ku, Tokyo 171-0021, Japan

\begin{abstract}
A thermophilic, Gram-positive bacterium that formed a branched vegetative mycelium was isolated from compost. The strain, designated $13^{\top}$, grew at temperatures between 35 and $62{ }^{\circ} \mathrm{C}$, with optimum growth at $50-55{ }^{\circ} \mathrm{C}$. No growth was observed below $29{ }^{\circ} \mathrm{C}$ or above $65{ }^{\circ} \mathrm{C}$. The $\mathrm{pH}$ range for growth was 5.7-10.0, the $\mathrm{pH}$ for optimum growth was 7.0 and no growth was observed below $\mathrm{pH} 5.6$ or above $\mathrm{pH}$ 10.8. The DNA G+C content of strain $13^{\top}$ was $69.2 \mathrm{~mol} \%$. The major fatty acids found were $\mathrm{C}_{15: 0}$ iso $(14.2 \%), \mathrm{C}_{15: 0}$ anteiso $(12.1 \%), \mathrm{C}_{17: 0}$ iso (16.3\%) and $\mathrm{C}_{17: 0}$ anteiso (21.7\%). The major menaquinones were MK-9 $\left(\mathrm{H}_{4}\right), \mathrm{MK}-10\left(\mathrm{H}_{4}\right)$ and MK$11\left(\mathrm{H}_{4}\right)$. The cell wall contained glutamic acid, glycine, alanine and LL-diaminopimelic acid in a molar ratio of $1.0: 3.9: 0.6: 0.5$. The polar lipids consisted of ninhydrin-positive phosphoglycolipids, phosphatidylglycerol, diphosphatidylglycerol and an unknown glycolipid. The cell-wall sugars were rhamnose and arabinose. 16S rRNA gene sequence analysis assigned this actinomycete to the family Nocardioidaceae, but its 16S rRNA gene sequence shared no more than $95.5 \%$ similarity with those of other members of the family. The chemotaxonomic and phenotypic characteristics of strain $13^{\top}$ differed in some respects from those of members of the genus Actinopolymorpha, the most closely related genus. Therefore, strain $13^{\top}$ represents a novel species in a new genus of the family Nocardioidaceae, for which the name Thermasporomyces composti gen. nov., sp. nov. is proposed. The type strain of the type species is $13^{\top}(=\mathrm{JCM}$ $16421^{\top}=$ DSM $22891^{\top}$ ).
\end{abstract}

The family Nocardioidaceae was described by Nesterenko et al. (1985). The name was validly published in 1990 (Nesterenko et al., 1990) and the description of the genus has since been emended by Zhi et al. (2009). At the time of writing, the family Nocardioidaceae comprised six genera: Nocardioides (Prauser, 1976), Aeromicrobium (Miller et al., 1991), Kribbella (Park et al., 1999; Sohn et al., 2003), Marmoricola (Urzì et al., 2000), Actinopolymorpha (Wang et al., 2001) and Jiangella (Song et al., 2005). All recognized species in this family are mesophilic. In this study, a new thermophilic actinomycete belonging to the family Nocardioidaceae was isolated from compost. In order to determine the taxonomic and phylogenetic position of this organism, the morphological, physiological and biochemical characteristics of the novel strain were examined and

Abbreviation: ISP, International Streptomyces Project.

The GenBank/EMBL/DDBJ accession number for the 16S rRNA gene sequence of Thermasporomyces composti $\mathrm{3}^{\mathrm{T}}$ is AB535715. the chemotaxonomic markers and 16S rRNA gene sequence were analysed. The results indicated that the new strain represented a novel species of a new genus.

The sample was obtained from mature compost produced by a field-scale composter (Hazaka system; Hazaka Plant Kogyo Co., Ltd), which was used for the treatment of livestock excreta. The composter was an open strip furrow ( $100 \mathrm{~m}$ long $\times 3 \mathrm{~m}$ wide $\times 2 \mathrm{~m}$ deep) with an automatic scoop-type turner. The details of this system have been described previously (Yabe et al., 2009). The sample was collected in a plastic bag (Ziploc), transported to the laboratory and stored at room temperature for 1 day.

The isolation medium was International Streptomyces Project (ISP) 3 agar (Shirling \& Gottlieb, 1966). The medium was supplemented with $20 \mathrm{mg} \mathrm{l}^{-1}$ trimethoprim, $10 \mathrm{mg} \mathrm{l}^{-1}$ nalidixic acid and $20 \mathrm{mg} \mathrm{l}^{-1}$ kanamycin. The sample ( $1 \mathrm{~g}$ wet weight) was serially diluted in saline solution and aliquots of the dilutions were spread on the 
plates. The plates were incubated at $50{ }^{\circ} \mathrm{C}$ for 7 days. One of the yellow and vegetative-mycelium-forming colonies was picked, grown and purified by plating three times on ISP 3 . The colony was restreaked and a stock culture was prepared by inoculating agar slants from the second plate. The isolate was designated strain $\mathrm{I}^{\mathrm{T}}$.

Cell morphology and colonial characteristics were determined after growth for 14 days at $50{ }^{\circ} \mathrm{C}$ on ISP $1,2,3,4,5$, 6 agars and nutrient agar by phase-contrast microscopy and visual inspection, respectively. A suitable agar block containing a colony grown at $50{ }^{\circ} \mathrm{C}$ for 14 days on ISP 3 agar was used for scanning electron microscopy (JSM6700F; JEOL) observations. The full details of the method were as previously described by Yabe et al. (2010).

Strain $\mathrm{I}^{\mathrm{T}}$ grew well on ISP 3 agar and weakly on ISP 2, 4, 6 agars and nutrient agar. No growth occurred on ISP 1 or ISP 5 agars. Strain $\mathrm{I}^{\mathrm{T}}$ developed pale yellow colonies on ISP 3, pale yellow-orange colonies on ISP 2 and white colonies on other media. No aerial mycelia or diffusible pigments were observed on any of the media. Strain $13^{\mathrm{T}}$ formed branched hyphae that fragmented into short chains or aggregates. The fragments were coccoid or short rods (Fig. 1). Spores were not observed.

In order to determine the effect of $\mathrm{pH}$, temperature and $\mathrm{NaCl}$ on growth, strain $\mathrm{I}^{\mathrm{T}}$ was cultivated in ISP 3 agar. Temperature, $\mathrm{pH}$ and $\mathrm{NaCl}$ tolerance tests were carried out at $20-65{ }^{\circ} \mathrm{C}(\mathrm{pH} 7.0), \mathrm{pH} 5.6-10.8\left(50{ }^{\circ} \mathrm{C}\right)$ and with $\mathrm{NaCl}$ $0-7 \%(\mathrm{w} / \mathrm{v})\left(50{ }^{\circ} \mathrm{C}, \mathrm{pH} 7.0\right)$. The $\mathrm{pH}$ was adjusted to various values with $\mathrm{HCl}$ and $\mathrm{NaOH}$ at room temperature. Biochemical tests were carried out using API ZYM microbial identification strips (bioMérieux). Physiological characteristics, including reaction with milk, sugar fermentation analyses, utilization of organic acids, gelatin liquefaction, and hydrolysis or decomposition of starch, Ltyrosine, xanthine, carboxymethylcellulose, xylan and casein were evaluated as described by Gordon et al. (1974). Gram staining was carried out by the modified Hucker method (Smibert \& Krieg, 1994). Catalase activity was determined by bubble production in a $3 \%(\mathrm{v} / \mathrm{v})$ hydrogen peroxide solution. The oxidase test was performed with cytochrome oxidase test paper (Nissui Seiyaku).

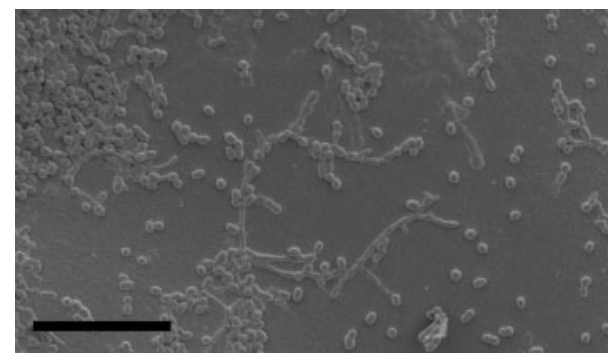

Fig. 1. Scanning electron micrograph of strain $13^{\top}$ grown on ISP 3 agar for 14 days at $50{ }^{\circ} \mathrm{C}$. Bar, $10 \mu \mathrm{m}$.
Strain $\mathrm{I} 3^{\mathrm{T}}$ stained Gram-positive and was catalase- and oxidase-positive. Growth occurred at temperatures between 35 and $62{ }^{\circ} \mathrm{C}$, with an optimum temperature of $50-55{ }^{\circ} \mathrm{C}$; there was no growth at $29{ }^{\circ} \mathrm{C}$ or $65{ }^{\circ} \mathrm{C}$. Strain $\mathrm{I} 3{ }^{\mathrm{T}}$ was able to grow over a $\mathrm{pH}$ range from 5.7 to 10.0, with an optimum at $\mathrm{pH}$ 7.0. No growth was observed at $\mathrm{pH} 5.6$ or 10.8. Growth was observed with up to $5 \%(\mathrm{w} / \mathrm{v}) \mathrm{NaCl}$. The results of the phenotypic examination of strain $13^{\mathrm{T}}$ are given in the species description.

Cellular fatty acids of strain $\mathrm{I}^{\mathrm{T}}$ were prepared from cell mass grown in nutrient broth for 5 days at $50{ }^{\circ} \mathrm{C}$ and then separated and identified with the Microbial Identification Systems (MIDI Inc.). Cell walls were prepared by the methods described by Schleifer \& Kandler (1972). The amino acids in the cell-wall hydrolysate were identified by TLC (Harper \& Davis, 1979) and HPLC as their phenylthiocarbamoyl derivatives with HPLC apparatus (LC-10AD; Shimadzu) equipped with a Wakopak WS-PTC column (Wako Pure Chemical Industries) as described by Yokota et al. (1993). Cell-wall sugars were determined as alditol acetate derivatives by GLC using a Shimadzu GC-17A equipped with a Rtx $2330(0.32 \mathrm{~mm} \times 30 \mathrm{~m})$ column. Phospholipids were extracted and identified using twodimensional TLC, followed by spraying with appropriate detection reagents according to the method of Tindall (1990a, b). Genomic DNA of the isolate was prepared using a method modified from Marmur (1961), in which achromopeptidase and lysozyme (final concentration 0.5 and $0.75 \mathrm{mg} \mathrm{ml}^{-1}$, respectively) were used for cell lysis. RNA was digested with RNase mix solution $\left(50 \mu \mathrm{ml}^{-1}\right)$ (Wako). The $\mathrm{G}+\mathrm{C}$ content (mol\%) of the genomic DNA was determined by HPLC (Tamaoka \& Komagata, 1984) using a COSMOSIL 5C 18-AR-II packed column (4.6 mm $\times$ $250 \mathrm{~mm}$; Nacalai Tesque) with the DNA-GC kit (Yamasa Shouyu).

The DNA G + C content of strain $\mathrm{I}^{\mathrm{T}}$ was $69.2 \mathrm{~mol} \%$, as determined by HPLC analysis. The predominant menaquinones were MK-9 $\left(\mathrm{H}_{4}\right)$, MK-10 $\left(\mathrm{H}_{4}\right)$ and MK-11 $\left(\mathrm{H}_{4}\right)$. The major fatty acids were $\mathrm{C}_{15: 0}$ iso $(14.2 \%), \mathrm{C}_{15: 0}$ anteiso $(12.1 \%), \mathrm{C}_{17: 0}$ iso $(16.3 \%)$ and $\mathrm{C}_{17: 0}$ anteiso $(21.7 \%)$. The polar lipids consisted of ninhydrin-positive phosphoglycolipids, phosphatidylglycerol, diphosphatidylglycerol and an unknown glycolipid. The peptidoglycan contained glutamic acid, glycine, alanine and LL-diaminopimelic acid in a molar ratio of $1.0: 3.9: 0.6: 0.5$. Cell-wall sugars were rhamnose and arabinose. Differential chemotaxonomic characteristics between strain $\mathrm{I}^{\mathrm{T}}$ and other genera belonging to the family Nocardioidaceae are summarized in Table 1.

A nearly complete $16 \mathrm{~S}$ rRNA gene sequence of strain $\mathrm{I}^{\mathrm{T}}$ was amplified by PCR and the purified PCR product was sequenced as described previously by Yabe et al. (2010). The 16S rRNA gene sequence of strain $\mathrm{I}^{\mathrm{T}}$ was compared with sequences obtained from GenBank. Multiple alignments of the sequences were performed using CLUSTAL $\mathrm{W}$ version 1.83 (Thompson et al., 1994) and gaps and 
Table 1. Differential characteristics of strain $13^{\top}$ and related taxa of the family Nocardioidaceae

Taxa: 1, Thermasporamyces composti gen. nov., sp. nov.; 2, Actinopolymorpha (data from Wang et al., 2001); 3, Jiangella (Song et al., 2005); 4, Kribbella (Park et al., 1999); 5, Nocardioides (Prauser, 1976; O’Donnell et al., 1982; Collins et al., 1989; Tamura \& Yokota, 1994; Miller et al., 1991; Park et al., 1999); 6, Aeromicrobium (Miller et al., 1991; Tamura \& Yokota, 1994); 7, Marmoricola (Urzì et al., 2000). PI, phosphatidylinositol; DPG, diphosphatidylglycerol; PIM, phosphatidylinositol mannosides; PG, phosphatidylglycerol; PC, phosphatidylcholine.

\begin{tabular}{|c|c|c|c|c|c|c|c|}
\hline Characteristic & 1 & 2 & 3 & 4 & 5 & 6 & 7 \\
\hline $\begin{array}{l}\text { Major } \\
\text { menaquinone }\end{array}$ & $\begin{array}{c}\text { MK-9 }\left(\mathrm{H}_{4}\right), \text { MK-10 }\left(\mathrm{H}_{4}\right), \\
\text { MK-11 }\left(\mathrm{H}_{4}\right)\end{array}$ & $\operatorname{MK}-9\left(\mathrm{H}_{6}\right)$ & $\operatorname{MK}-9\left(\mathrm{H}_{4}\right)$ & MK-9 $\left(\mathrm{H}_{4}\right)$ & $\mathrm{MK}-8\left(\mathrm{H}_{4}\right)$ & $\operatorname{MK}-9\left(\mathrm{H}_{4}\right)$ & $\mathrm{MK}-8\left(\mathrm{H}_{4}\right)$ \\
\hline Major fatty acids & $\begin{array}{c}\mathrm{C}_{15: 0} \text { iso, } \mathrm{C}_{15: 0} \\
\text { anteiso, } \mathrm{C}_{17: 0} \text { iso } \\
\mathrm{C}_{17: 0} \text { anteiso }\end{array}$ & $\begin{array}{c}\mathrm{C}_{15: 0} \text { iso, } \mathrm{C}_{16: 0} \text { iso, } \\
\mathrm{C}_{16: 1^{-1 s o-H}}\end{array}$ & $\begin{array}{c}\mathrm{C}_{15: 0} \\
\text { anteiso, } \\
\mathrm{C}_{16: 0} \text { iso }\end{array}$ & $\begin{array}{c}\mathrm{C}_{15: 0} \\
\text { anteiso, } \\
\mathrm{C}_{16: 0} \text { iso }\end{array}$ & $\mathrm{C}_{16: 0}$ iso & $\begin{array}{c}\mathrm{C}_{16: 0}, \mathrm{C}_{16: 0} 2-\mathrm{OH}, \\
\mathrm{C}_{18: 0-10-\mathrm{Me}} \\
\mathrm{C}_{18: 1} \omega 9 c\end{array}$ & $\begin{array}{l}\mathrm{C}_{16: 0}, \mathrm{C}_{18: 1} \\
\left(\mathrm{C}_{16: 0} \text { iso }\right) \dagger\end{array}$ \\
\hline Phospholipids & PG, DPG & PIM, PI, PG, (DPG)* & $\begin{array}{l}\text { PIM, PI, } \\
\text { DPG }\end{array}$ & $\mathrm{PC}$ & PG & PG, DPG & PI, PG, DPG \\
\hline
\end{tabular}

*Actinopolymorpha cephalotaxi lacks DPG.

$\dagger$ Major fatty acid of Marmoricola bigeumensis is $\mathrm{C}_{16: 0}$ iso.

unidentified base positions were edited using BioEdit (Hall, 1999). Phylogenetic trees were constructed with the maximum-likelihood method (Felsenstein, 1981) using PhyML (Guindon \& Gascuel, 2003), the neighbour-joining method (Saitou \& Nei, 1987), and the maximumparsimony method (Fitch, 1971) using MEGA version 4.1 (Tamura et al., 2007), with bootstrap values based on 100, 1000 and 1000 replications, respectively (Felsenstein,

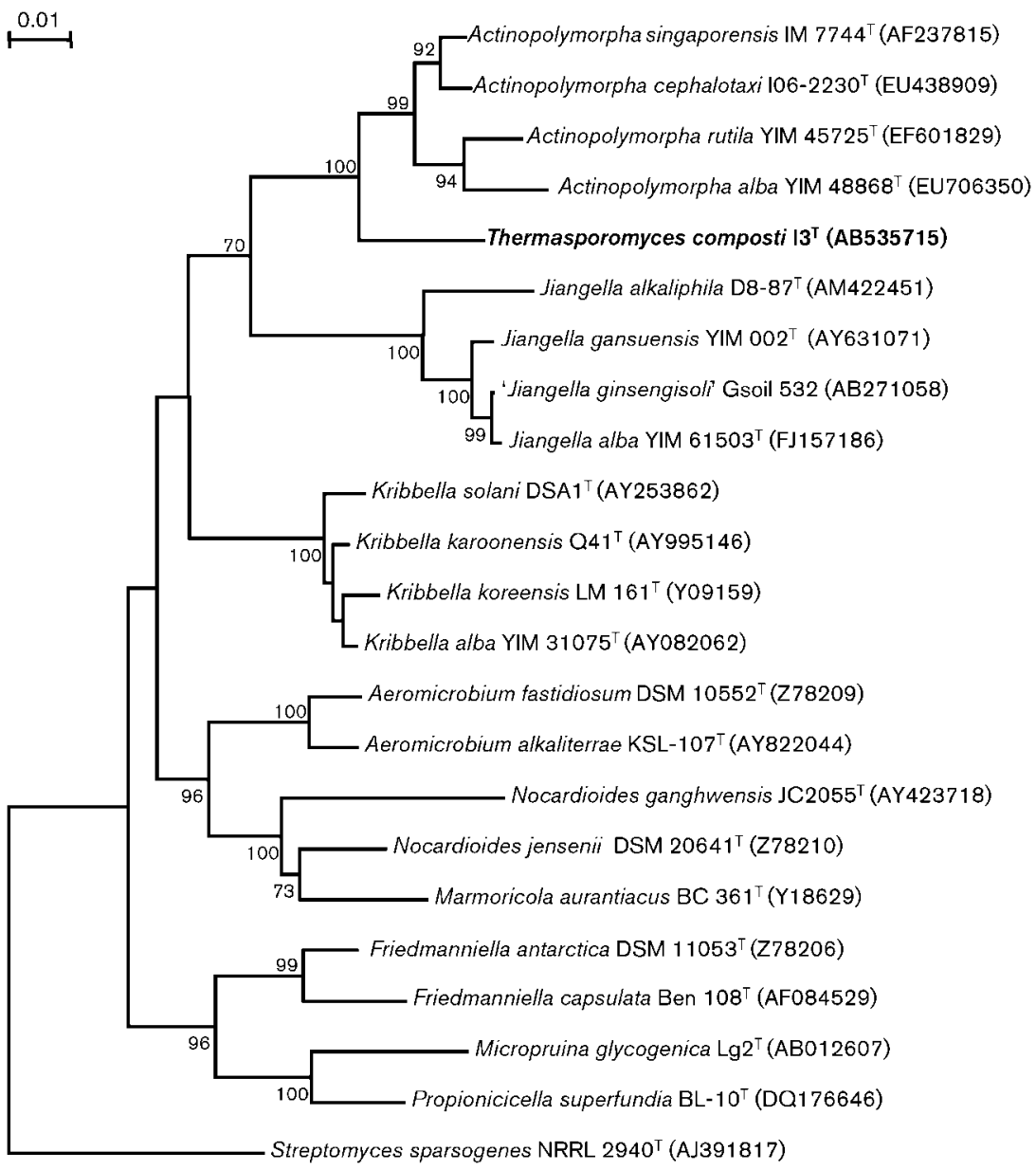

Fig. 2. Neighbour-joining tree based on 1310 aligned positions of the 16S rRNA gene sequence showing the position of strain $13^{\top}$ in relation to other members of the family Nocardioidaceae. The sequence of Streptomyces sparsogenes NRRL $2940^{\top}$ was used as the outgroup. The numbers at the nodes are bootstrap percentages based on 1000 replicated datasets; only values $\geqslant 70 \%$ are shown. Bar, $1 \%$ sequence dissimilarity. 
1985). The evolutionary distances were computed using the Kimura two-parameter method (Kimura, 1980).

A phylogenetic tree was constructed based on 16S rRNA gene sequences (Fig. 2). All trees had similar topologies. The $16 \mathrm{~S}$ rRNA gene sequence similarities between strain $\mathrm{I}^{\mathrm{T}}$ and its closest relatives were as follows: Actinopolymorpha cephalotaxi $\mathrm{I} 06-2230^{\mathrm{T}}(95.5 \%)$, Actinopolymorpha rutila YIM $45725^{\mathrm{T}}(95.5 \%)$, Actinopolymorpha alba YIM $48868^{\mathrm{T}}$ (95.5\%) and Actinopolymorpha singaporensis IM $7744^{\mathrm{T}}$ $(95.3 \%)$. The 16S rRNA gene sequence similarities between strain $13^{\mathrm{T}}$ and members of other genera were less than $93 \%$.

The results of the phylogenetic analysis suggest that strain $\mathrm{I} 3^{\mathrm{T}}$ should be placed in the family Nocardioidaceae. However, strain $\mathrm{I}^{\mathrm{T}}$ had low $16 \mathrm{~S}$ rRNA gene sequence similarities with members of the genus Actinopolymorpha (95.3-95.5\%) and was separated from its closest neighbours (species of the genus Actinopolymorpha) by a long branch in the phylogenetic tree (Fig. 2). Furthermore, strain $\mathrm{I}^{\mathrm{T}}$ was thermophilic, whereas other species in the family Nocardioidaceae, including species of the genus Actinopolymorpha, are mesophilic. The chemotaxonomic properties of strain $\mathrm{I} 3^{\mathrm{T}}$ were very distinct from those of other species of the genus Actinopolymorpha, for example, strain $\mathrm{I}^{\mathrm{T}}$ had MK-11 $\left(\mathrm{H}_{4}\right)$ as one of its major menaquinones and no phosphatidylinositol or phosphatidylinositol mannosides (Table 1). Therefore, strain $\mathrm{I}^{\mathrm{T}}$ represents a novel species in a new genus of the family Nocardioidaceae, for which the name Thermasporomyces composti gen. nov., sp. nov. is proposed.

\section{Description of Thermasporomyces gen. nov.}

Thermasporomyces [Ther.ma.spo.ro.my'ces. Gr. n. therme heat; Gr. prefix. a not; Gr. n. spora a seed, and in biology a spore; Gr. masc. n. mukes mushroom or other fungus; N.L. masc. n. Thermasporomyces the heat (-loving) non-spored fungus].

Gram-positive, aerobic, heterotrophic bacteria that produce branched vegetative mycelium. No spores are observed. Good growth occurs on ISP 3 medium. Growth occurs between 35 and $62{ }^{\circ} \mathrm{C}$ (optimum $50-55^{\circ} \mathrm{C}$ ), pH 5.7-10.0 (optimum $\mathrm{pH} 7.0)$ and in the presence of up to $5 \%(\mathrm{w} / \mathrm{v})$ $\mathrm{NaCl}$. The major fatty acids are $\mathrm{C}_{15: 0}$ iso, $\mathrm{C}_{15: 0}$ anteiso, $\mathrm{C}_{17: 0}$ iso and $\mathrm{C}_{17: 0}$ anteiso. The major menaquinones are MK-9 $\left(\mathrm{H}_{4}\right)(41.2 \%)$, MK-10 $\left(\mathrm{H}_{4}\right)(27.7 \%)$ and MK-11 $\left(\mathrm{H}_{4}\right)$ $(30.8 \%)$. The cell wall contains glutamic acid, glycine, alanine and LL-diaminopimelic acid in a molar ratio of $1.0: 3.9: 0.6: 0.5$. The polar lipids consist of ninhydrinpositive phosphoglycolipids, phosphatidylglycerol, diphosphatidylglycerol and an unknown glycolipid. Cell-wall sugars are rhamnose and arabinose. The type species is Thermasporomyces composti.

\section{Description of Thermasporomyces composti sp. nov.}

Thermasporomyces composti (com.pos'ti. N.L. n. compostum -i compost; N.L. gen. n. composti of compost).
Exhibits the following properties in addition to those given in the genus description. Catalase- and oxidase-positive. Positive for nitrate reduction, gelatin hydrolysis, milk coagulation and peptonization. Casein, carboxymethylcellulose and xylan are hydrolysed, while starch, xanthine and L-tyrosine are not hydrolysed. Utilizes raffinose, sorbitol, lactose, cellobiose and D-arabinose, but not sodium citrate or sodium succinate. Acid is produced from mannose and maltose, but not from L-rhamnose, sorbitol, inositol or D-galactose. Enzymic activities detected by API ZYM are alkaline phosphatase, C4 and C8 esterases, leucine arylamidase, $\alpha$-chymotrypsin, naphthol phosphohydrolase, trypsin, $\alpha$-galactosidase, $\alpha$-glucosidase, lipase $\mathrm{C} 14$, valine arylamidase, $N$-acetyl- $\beta$-glucosaminidase and $\alpha$-mannosidase. Activities not detected by API ZYM are $\beta$-galactosidase, $\beta$ glucosidase, $\beta$-glucuronidase and $\alpha$-fucosidase.

The type strain is $\mathrm{I}^{\mathrm{T}}\left(=\mathrm{JCM} 16421^{\mathrm{T}}=\mathrm{DSM} 22891^{\mathrm{T}}\right)$. The DNA G + C content of the type strain is $69.2 \mathrm{~mol} \%$.

\section{Acknowledgements}

This work was partly supported by the Center for Integrated Nanotechnology Support at Tohoku University and also by 'Nanotechnology Network Project' of the Ministry of Education, Culture, Sports, Science, and Technology (MEXT) of the Japanese Government. We thank Eiji Aoyagi (Institute for Materials Research, Tohoku University) for SEM technical guidance, and thank Ms Kim Jeeyoung for help with the $\mathrm{G}+\mathrm{C}$ content and cell wall analysis. We acknowledge Professor Dr Jean Euzéby for support in the Latin etymology of the new genus names.

\section{References}

Collins, M. D., Dorsch, M. \& Stackebrandt, E. (1989). Transfer of Pimelobacter tumescens to Terrabacter gen. nov. as Terrabacter tumescens comb. nov. and of Pimelobacter jensenii to Nocardioides as Nocardioides jensenii comb. nov. Int J Syst Bacteriol 39, 1-6.

Felsenstein, J. (1981). Evolutionary trees from DNA sequences: a maximum likelihood approach. J Mol Evol 17, 368-376.

Felsenstein, J. (1985). Confidence limits on phylogenies: an approach using the bootstrap. Evolution 39, 783-791.

Fitch, W. M. (1971). Toward defining the course of evolution: minimum change for a specific tree topology. Syst Zool 20, 406416.

Gordon, R. E., Barnett, D. A., Handerhan, J. E. \& Pang, C. H.-N. (1974). Nocardia coeliaca, Nocardia autotrophica, and the nocardin strain. Int J Syst Bacteriol 24, 54-63.

Guindon, S. \& Gascuel, O. (2003). A simple, fast, and accurate algorithm to estimate large phylogenies by maximum likelihood. Syst Biol 52, 696-704.

Hall, T. A. (1999). BioEdit: a user-friendly biological sequence alignment editor and analysis program for Windows 95/98/NT. Nucleic Acids Symp Ser 41, 95-98.

Harper, J. J. \& Davis, G. H. G. (1979). Two-dimensional thin-layer chromatography for amino acid analysis of bacterial cell walls. Int $J$ Syst Bacteriol 29, 56-58.

Kimura, M. (1980). A simple method for estimating evolutionary rates of base substitutions through comparative studies of nucleotide sequences. J Mol Evol 16, 111-120. 
Marmur, J. (1961). A procedure for the isolation of deoxyribonucleic acid from microorganisms. J Mol Biol 3, 208-218.

Miller, E. S., Woese, C. R. \& Brenner, S. (1991). Description of the erythromycin-producing bacterium Arthrobacter sp. strain NRRL B3381 as Aeromicrobium erythreum gen. nov., sp. nov. Int J Syst Bacteriol 41, 363-368.

Nesterenko, O. A., Kvasnikov, E. I. \& Nogina, T. M. (1985). Nocardioidaceae fam. nov., a new family of the order Actinomycetales Buchanan 1917. Mikrobiol Zh 47, 3-12.

Nesterenko, O. A., Kvasnikov, E. I. \& Nogina, T. M. (1990). Nocardioidaceae fam. nov. In Validation of the Publication of New Names and New Combinations Previously Effectively Published Outside the IJSB, List no. 34. Int J Syst Bacteriol 40, 320-321.

O’Donnell, A. G., Goodfellow, M. \& Minnikin, D. E. (1982). Lipids in the classification of Nocardioides: reclassification of Arthrobacter simplex (Jensen) Lochhead in the genus Nocardioides (Prauser) emend. O'Donnell et al. as Nocardioides simplex comb. nov. Arch Microbiol 133, 323-329.

Park, Y. H., Yoon, J. H., Shin, Y. K., Suzuki, K., Kudo, T., Seino, A., Kim, H. J., Lee, J. S. \& Lee, S. T. (1999). Classification of 'Nocardioides fulvus' IFO 14399 and Nocardioides sp. ATCC 39419 in Kribbella gen. nov., as Kribbella flavida sp. nov. and Kribbella sandramycini sp. nov. Int J Syst Bacteriol 49, 743-752.

Prauser, H. (1976). Nocardioides, a new genus of the order Actinomycetales. Int J Syst Bacteriol 26, 58-65.

Saitou, N. \& Nei, M. (1987). The neighbor-joining method: a new method for reconstructing phylogenetic trees. Mol Biol Evol 4, 406425 .

Schleifer, K. H. \& Kandler, O. (1972). Peptidoglycan types of bacterial cell walls and their taxonomic implications. Bacteriol Rev 36, 407477.

Shirling, E. B. \& Gottlieb, D. (1966). Methods for characterization of Streptomyces species. Int J Syst Bacteriol 16, 313-340.

Smibert, R. M. \& Krieg, N. L. (1994). Phenotypic characterization. In Methods for General and Molecular Bacteriology, pp. 607-654. Edited by P. Gerhardt, R. G. E. Murray, W. A. Wood \& N. R. Krieg. Washington, DC: American Society for Microbiology.

Sohn, K., Hong, S. G., Bae, K. S. \& Chun, J. (2003). Transfer of Hongia koreensis Lee et al. 2000 to the genus Kribbella Park et al. 1999 as Kribbella koreensis comb. nov. Int J Syst Evol Microbiol 53, 10051007.

Song, L., Li, W. J., Wang, Q. L., Chen, G. Z., Zhang, Y. S. \& Xu, L. H. (2005). Jiangella gangsuensis gen. nov., sp. nov., a novel actinomycete from a desert soil in north-west China. Int J Syst Evol Microbiol 55, 881-884.

Tamaoka, J. \& Komagata, K. (1984). Determination of DNA base composition by reversed-phase high-performance liquid chromatography. FEMS Microbiol Lett 25, 125-128.

Tamura, T. \& Yokota, A. (1994). Transfer of Nocardioides fastidiosa Collins and Stackebrandt 1989 to the genus Aeromicrobium as Aeromicrobium fastidiosum comb. nov. Int J Syst Bacteriol 44, 608-611.

Tamura, K., Dudley, J., Nei, M. \& Kumar, S. (2007). MEGA4: Molecular evolutionary genetics analysis (MEGA) software version 4.0. Mol Biol Evol 24, 1596-1599.

Thompson, J. D., Higgins, D. G. \& Gibson, T. J. (1994). CLUSTAL W: improving the sensitivity of progressive multiple sequence alignment through sequence weighting, position-specific gap penalties and weight matrix choice. Nucleic Acids Res 22, 4673-4680.

Tindall, B. J. (1990a). A comparative study of the lipid composition of Halobacterium saccharovorum from various sources. Syst Appl Microbiol 13, 128-130.

Tindall, B. J. (1990b). Lipid composition of Halobacterium lacusprofundi. FEMS Microbiol Lett 66, 199-202.

Urzi, C., Salamone, P., Schumann, P. \& Stackebrandt, E. (2000). Marmoricola aurantiacus gen. nov., sp. nov., a coccoid member of the family Nocardioidaceae isolated from a marble statue. Int J Syst Evol Microbiol 50, 529-536.

Wang, Y. M., Zhang, Z. S., Xu, X. L., Ruan, J. S. \& Wang, Y. (2001). Actinopolymorpha singaporensis gen. nov., sp. nov., a novel actinomycete from the tropical rainforest of Singapore. Int J Syst Evol Microbiol 51, 467-473.

Yabe, S., Kato, A., Hazaka, M. \& Yokoto, A. (2009). Thermaerobacter composti sp. nov., a novel extremely thermophilic bacterium isolated from compost. J Gen Appl Microbiol 55, 323-328.

Yabe, S., Aiba, Y., Sakai, Y., Hazaka, M. \& Yokota, A. (2010). Thermosporothrix hazakensis gen. nov., sp. nov., isolated from compost and description of Thermosporotrichaceae fam. nov. within the class Ktedonobacteria. Int J Syst Evol Microbiol 60, 1794-1801.

Yokota, A., Tamura, T., Nishii, T. \& Hasegawa, T. (1993). Kineococcus aurantiacus gen. nov., sp. nov., a new aerobic Gram-positive, motile coccus with meso-diaminopimelic acid and arabinogalactan in the cell wall. Int J Syst Bacteriol 43, 52-57.

Zhi, X. Y., Li, W. J. \& Stackebrandt, E. (2009). An update of the structure and 16S rRNA gene sequence-based definition of higher ranks of the class Actinobacteria, with the proposal of two new suborders and four new families and emended descriptions of the existing higher taxa. Int J Syst Evol Microbiol 59, 589-608. 